\title{
Waste Cooking Oil as Substrate for Single Cell Protein Production by Yeast Yarrowia Lipolytica
}

\author{
Kriss SPALVINS ${ }^{1}$ *, Zane GEIBA ${ }^{2}, Z^{2}$ ane KUSNERE ${ }^{3}$, Dagnija BLUMBERGA ${ }^{4}$ \\ ${ }^{1-4}$ Riga Technical University, Institute of Energy Systems and Environment, Azenes iela 12/1, \\ Riga, LV 1048, Latvia
}

\begin{abstract}
Cooking oils are widely used in food preparation. During cooking, harmful compounds are formed in oils, therefore utilization of used cooking oils (waste cooking oils) is limited. Single cell protein (SCP) is dietary protein, which can be produced from various protein-rich microorganisms that are capable of utilizing industrial by-products such as waste cooking oil (WCO). In this study the utilization of industrial WCO (obtained from local potato chips manufacturer) as a carbon source for single cell protein production by yeast Yarrowia lipolytica was assessed. The medium containing $27.5 \mathrm{~g} / \mathrm{L}$ WCO and $\mathrm{C} / \mathrm{N}$ ratio of 5-10 for batch fermentations was determined to be the optimal composition for SCP production. In this study, the highest reported Yarrowia lipolytica biomass concentration $(57.37 \mathrm{~g} / \mathrm{L})$ was achieved when WCO was used as the main carbon source. Protein concentrations were relatively low $(12.6 \%)$, which also affected the final protein yield $(7.23 \mathrm{~g} / \mathrm{L})$. The resulting biomass accumulated low concentrations of toxic malondialdehyde (MDA) $(2.32 \mathrm{mg}$ MDA/ $/ \mathrm{kg})$ compared to concentrations initially detected in the WCO itself $(30.87 \mathrm{mg} \mathrm{MDA} / \mathrm{kg})$. To the best of the authors knowledge this is the first study to report on MDA decrease via microbial fermentations.
\end{abstract}

Keywords - Agricultural residues; animal feed; low-cost substrate; malondialdehyde; microbial protein; TBARS test; used cooking oil

\section{INTRODUCTION}

Vegetable oils are widely used in cooking around the world. Vegetable oils are used in households, diners and food production at industrial scale. During frying, harmful compounds are formed in the oils [1] and for this reason frying oils must be changed regularly. These used cooking oils are called waste cooking oils (WCO). Approximately 10 million tons of WCO are generated worldwide each year [1]. Large amounts of WCO are discarded without proper treatment. Theoretically, one litre of oil can contaminate up to 1 million litres of water [2] and WCO is characterized by very high COD and BOD values, so WCO treatment is very important to reduce the negative environmental impact of these residues. In addition, more than $80 \%$ of vegetable oils are consumed in households [3], [4], therefore it also puts a significant strain on municipal wastewater treatment systems, clogging pipelines and causing water pollution if these oils are not treated properly. In order not to incur additional costs in treatment of the generated WCO, a good approach is to use these oils as a raw material in the

* Corresponding author.

E-mail address: Kriss.Spalvins@rtu.lv 
production of new products, thus not only generating additional income, but also recycling $\mathrm{WCO}$, which in turn reduces the negative impact on the environment. WCO is two to three times cheaper than vegetable oils, so its use offers significant economic benefits [5]. WCO is currently used as a feedstock in animal feeds, soap production, oleochemical industries and biodiesel production [4], [6], [7]. However, the use of WCO as an additive in animal feeds has been banned in the European Union since 2002, as there is a risk that harmful compounds in WCO will end up in animal products and therefore in human diets [8], [9]. This ban is justified, because during frying, vegetable oils hydrolyze, oxidize and polymerize. Oxidation results in the formation of hydroperoxides, aldehydes, carnations, carboxylic acids, alkanes and alkenes in the oil [10]. Particularly harmful are the various aldehydic end-products that occur in frying oils during heating. They can cause a variety of health problems, such as atherosclerosis [11], ischemic heart disease, peripheral vascular disease etc. [12]. WCO can be purified using existing technological solutions that are widely used to refine raw vegetable oils, such as treatment with activated earth [13], bleaching, degumming and deodorizing processes [1], [14]. By using these methods, it is possible to get rid of most oxidation products, however, some harmful compounds such as malondialdehyde remain in the oil even after the above-mentioned purification measures [1], [15].

During heating, polyunsaturated fatty acids in oils are oxidized to form hydroperoxides, which, as oxidation continues, form secondary oxidation products such as malondialdehyde (MDA) [16], [17]. MDA is able to form adducts with proteins and DNA molecules, so MDA is recognized as a potent mutagen in humans [16], [18]-[20]. Determination of MDA concentration in fish and meat products is often used to determine the degree of lipid oxidation [16]. MDA concentrations are usually determined using spectrophotometric measurement of the violet adduct formed by the reaction of MDA with 2-thiobarbituric acid (TBA) [16], [21], this test is called the TBARS test. This method is often criticized for the non-specificity of the reaction, as compounds in products such as browning reaction products, sugar degradation products and proteins also react with TBA [1], thus increasing the measurement error [16], [22], [23]. For this reason, the possibility of replacing the TBARS test with more specific high-performance liquid chromatography (HPLC) analytical techniques has been discussed [1], [16], [24]. Although more accurate, HPCL assays are much more expensive, time consuming, and complex than classical colorimetric assays [16]. Papastergiadis et al. [16] compared the TBARS assay with HPLC analysis coupled with fluorescence detection. In these studies, there was no significant difference between the TBARS test and HPLC analysis results for products such as oils, raw, uncooked meat and fish products, while processed products such as nuts, meat, fish products and cheese showed significantly higher MDA concentrations in the TBARS tests than in HPLC analysis [16]. This suggests that TBARS analysis is useful and can be considered accurate when MDA is measured in raw products and oils. In this study, MDA was measured using TBARS test in oils and in raw yeast biomass, which is similar in macromolecular composition to meat products. Permissible MDA concentrations in meat products are below $2.0 \mathrm{mg} \mathrm{MDA} / \mathrm{kg}$ of sample [25]. Lipids can be characterized as not rancid if MDA concentration is below $1.5 \mathrm{mg} / \mathrm{kg}$ of oil, slightly rancid from 1.6 to $3.6 \mathrm{mg} / \mathrm{kg}$, and rancid above $3.7 \mathrm{mg} / \mathrm{kg}$ [25] [27].

The energy capacity of oils is about twice that of glucose, making WCO a very suitable substrate for culturing microorganisms that are able to use such substrates efficiently [28]. Due to its high energy capacity, low cost and wide availability, the use of WCO in microbiological fermentations is a promising alternative for the production of various value added products. In addition, the use of WCO in fermentations also ensures the treatment of 
WCO, thus also reducing the strain on the environment. To date, the potential of WCO used as a substrate in microbiological fermentations has been reported for the production of single cell oils [2], [29]-[32] single cell proteins [32], [33], sophorolipids [13], carotene [4], erithryol [28], [34] lipase [32]-[36] and citric acid [28], [37].

Single cell proteins (SCP) are known as dietary single-cell microorganisms whose biomass or protein extracts are derived from pure or mixed microscopic algae, yeasts, mushrooms or bacterial cultures [38]. These microorganisms can be used as protein-rich foods or food ingredients or dietary supplements [39], but they are mainly used as food for human and animal consumption [40]. SCPs are a good alternative to replacing protein of agricultural origin, since SCP production is not characterized by high water consumption [41], it does not cover large areas of land, does not endanger environmental diversity [42], does not contribute to climate change and does not produce high greenhouse gas emissions [43], as it is the case with agriculture. To reduce the cost of production of SCP, it is essential to use biodegradable agro-industrial by-products and wastes such as WCO as a source of nutrients for the cultivation of microorganisms. All potentially applicable by-products for production of single cell proteins and single cell oils have been reviewed by Spalvins et al. [52]-[54].

Although WCO has the potential to process microbiological fermentations, existing oil degradation products such as peroxides, hydroperoxides, aldehydes, and ketones in WCO can negatively affect the metabolism of microorganisms and reduce the yield of fermentation products [13]. Therefore, when using WCO as a substrate in the production of unicellular proteins, it is necessary to check the concentrations of undesired compounds. If WCO is fermented to produce SCP, there is a risk that MDA will accumulate in the biomass of the cultured microorganisms and thus in the final product itself. Therefore, the SCP produced by fermenting WCO needs to be tested for the accumulation of MDA.

Among the various groups of microorganisms, such as bacteria, yeasts, fungi, and microalgae, yeasts are highly effective for growth on a variety of substrates, including a wide variety of agro-industrial by-products [44]. Yeasts are able to use sugars, glycerol, acetate and ethanol as carbon sources [45], but far fewer microorganisms are able to effectively use hydrophobic carbon sources such as oils. Yeast from genera such as Cryptococcus, Trichosporon, Rhodosporidium, Geotrichum and Yarrowia are known to be able to use hydrophobic substrates [46]. Yarrowia lipolytica is a widely studied microorganism in this respect, as it is not only able to efficiently use oils as the main carbon source, but its metabolic pathways allow for the utilization of hydrophobic substrates such as fatty acids, alkanes and triglycerides [46]. Extracellular lipases secreted by the yeast cleave lipids to free fatty acids, which are then diffused into cells at a favourable concentration gradient or transported using active transporters [47], [48]. Hydrophobic substrates are generally insoluble in water and form layer on the surface of the medium, making them inaccessible to cultured microorganisms. Yarrowia lipolytica is able to produce extracellular emulsifiers that increase the miscibility of hydrophobic substrates and thus make the relevant nutrients available to yeast [45], [49]. For this reason, the ability of Yarrowia lipolytica to use untreated WCO was also tested in this study. In other studies, where WCO is used as a substrate, the oil is usually emulsified by either adding oil emulsifying polysorbates to the media or ultrasonicating the medium, however, this increases the total cost of the medium. Yarrowia lipolytica is considered safe for human consumption, is tolerant to contamination, low oxygen concentrations, heavy metals and has extensive tools for genetic modification [37].

This is not the first time when SCP production is attempted by using WCO as the main carbon source. Papanikolaou et al. [32] reported on simultaneous production of single cell oil, single cell protein and lipase from tallow by Yarrowia lipolytica [32], although 
emulsifiers were used for the preparation of the medium. Yan et al. [33] reported on simultaneous SCP and lipase production by genetically engineered Yarrowia lipolytica, by using WCO as substrate [33], but this report lacked in-depth optimization of WCO medium, which is understandable since that was not the main focus of the study. To the best of authors' knowledge, this is the first study that focuses solely on SCP production by Yarrowia lipolytica when untreated WCO is used as the main carbon source.

\section{Materials AND Methods}

\subsection{Waste Cooking Oil, Yarrowia Lipolytica}

Waste cooking oil was kindly provided by the local potato chip manufacturer JSC "LATFOOD". For the preparation of chips, the company uses sunflower oil, therefore, to calculate the $\mathrm{C} / \mathrm{N}$ ratios in the media, the proportion of fatty acids in sunflower oil was assumed to be as follows: palmitic acid $6.80 \%$, stearic acid $3.26 \%$, oleic acid $16.93 \%$, linoleic acid $\left(\mathrm{C}_{18: 2}\right) \quad 0.56 \%$, linoleic acid $\left(\mathrm{C}_{18: 3}\right) 71.73 \%$ [50].

Yarrowia lipolytica wild type, was kindly provided by Dr. biol. Vizma Nikolajeva from Microbial Strain Collection of Latvia, University of Latvia. The strain was cultured on malt extract agar plates at $28{ }^{\circ} \mathrm{C}$ for 1 week and then stored in fridge at $4{ }^{\circ} \mathrm{C}$.

\subsection{Medium Preparation}

Three different oil samples were prepared for use in the cultivation experiments:

1. Refined sunflower oil (SFO) purchased from a local supermarket;

2. The second oil sample was prepared by treating the same store-bought sunflower oil by heating it at $170{ }^{\circ} \mathrm{C}$ for 48 hours (TSFO). The oil treatment in the laboratory was used according to the potato chip manufacturer's instructions on how often they change and at what temperature they heat the sunflower oil in their factory;

3. The aforementioned WCO an industrial sunflower oil (ISFO) provided by local potato chips manufacturer.

Three different control mediums were used in the culture experiments:

1. YEP medium consisted of yeast extract $(10 \mathrm{~g} / \mathrm{L})$, peptone from meat $(10 \mathrm{~g} / \mathrm{L})$, glucose (23.66 g/L, which is equivalent to $12.5 \mathrm{~g} / \mathrm{L}$ of sunflower oil), sodium chloride $(5 \mathrm{~g} / \mathrm{L})$. All components were dissolved in distilled water and autoclaved;

2. YNB medium consisted of yeast nitrogen base without amino acids and ammonium sulphate $(1.7 \mathrm{~g} / \mathrm{L})$, sodium chloride $(5 \mathrm{~g} / \mathrm{L})$, glucose $(23.66 \mathrm{~g} / \mathrm{L})$, urea $(1.39 \mathrm{~g} / \mathrm{L})$, for the $\mathrm{C} / \mathrm{N}$ ratio of 15 .

3. SFO and (4) TSFO mediums consisted of yeast nitrogen base without amino acids and ammonium sulphate $(1.7 \mathrm{~g} / \mathrm{L})$, sodium chloride $(5 \mathrm{~g} / \mathrm{L})$, corresponding SFO or TSFO oils $(12.5 \mathrm{~g} / \mathrm{L})$, urea $(1.39 \mathrm{~g} / \mathrm{L})$, for the $\mathrm{C} / \mathrm{N}$ ratio of 15 .

ISFO media consisted of yeast nitrogen base without amino acids and ammonium sulphate $(1.7 \mathrm{~g} / \mathrm{L})$, sodium chloride $(5 \mathrm{~g} / \mathrm{L})$, and ISFO oil concentrations and urea concentrations were changed to prepare media with different oil concentrations and $\mathrm{C} / \mathrm{N}$ ratios.

The $\mathrm{C} / \mathrm{N}$ ratios calculated for all media represent the mass ratio of carbon to nitrogen. For YNB, SFO, TSFO and ISFO media, all components except oils were dissolved in distilled water and filter sterilized using a 0.2 um filter. Oil samples were autoclaved and then added to the otherwise complete SFO, TSFO and ISFO mediums. 


\subsection{Cultivation Experiments}

Pre-culture of Yarrowia lipolytica WT was prepared by introducing couple of colonies from agar plate in $50 \mathrm{ml}$ flask containing $15 \mathrm{ml}$ of liquid YEP medium. It was cultivated overnight under shaking at $200 \mathrm{rpm}$ and $28{ }^{\circ} \mathrm{C} .1 \mathrm{ml}$ of overnight culture was centrifuged at $4000 \mathrm{rpm}$ for $10 \mathrm{~min}$, supernatant was decanted and cell pellet was resuspended in $1 \mathrm{ml}$ of distilled sterile water, then centrifugation, removal of supernatant and resuspention in water was repeated so the most of the medium would be washed out. Cell concentration in the washed and resuspended sample was determined by counting the cells in hemocitometer and then adding appropriate volume so $1 \cdot 10^{5} \mathrm{cells} / \mathrm{ml}$ of medium would be added in each flask containing appropriate medium.

Cultivation experiments were performed in $50 \mathrm{ml}$ flasks containing $15 \mathrm{ml}$ of medium. Each control medium and the variants of the ISFO mediums were done in triplets. Cultivation was done under shaking at $200 \mathrm{rpm}, 28^{\circ} \mathrm{C}$, for 5 days.

\subsection{Biomass, Protein and MDA Analysis}

Biomass analysis was performed every day using a gravimetric method following a modification by Sestric et al. [51] in which the biomass was washed with hexane to separate excess oil from the biomass.

Before determining the protein concentration, biomass samples were lysed by adding $1 \mathrm{ml}$ of $2.5 \%$ SDS $0.2 \mathrm{M} \mathrm{NaOH}$ mixture to each sample $(\sim 0.01-0.05 \mathrm{~g})$, then $0.5 \mathrm{~mm}$ glass beads (Retsch) were added to the samples, the samples were vortexed for 5 minutes, then placed in a water bath at $100{ }^{\circ} \mathrm{C}$ for $5 \mathrm{~min}$ and then vortexed again for 30 seconds. Protein concentration in biomass was determined using Total Protein Kit, Micro Lowry, Peterson's Modification (Sigma). Spectrophotometric measurements were performed using a UV-Vis spectrophotometer BioMate 160 (Thermo Scientific).

MDA concentrations were measured for both SFO, TSFO, ISFO oil samples, and also for cell biomass samples at days 1 and 4, for samples cultured using the optimal SFO, TSFO and ISFO mediums. MDA concentration was determined using a lipid peroxidation assay kit (Sigma). Colorimetric measurements were performed using a UV-Vis spectrophotometer BioMate 160 (Thermo Scientific).

\section{RESULTS AND DISCUSSION}

\subsection{Comparison with Controls}

Protein yields of Yarrowia lipolytica cultures growing on YEP medium were approximately 2-fold higher than all other mediums when the same carbon concentrations were used, be it from glucose or oil (Fig. 1). Due to the unknown exact composition of yeast extract and peptone, the $\mathrm{C} / \mathrm{N}$ ratio for YEP medium is unknown, but due to the high concentrations of proteins and free amino acids in these ingredients it is safe to assume that it is significantly lower than the $\mathrm{C} / \mathrm{N} 15$ used in other mediums.

There were significant differences between the three types of medium that used oil as the main carbon source (SFO, TSFO, ISFO) (Fig. 1). The treated sunflower oil, lagged significantly behind the other two mediums during the first three days of cultivation, on the fourth day the protein yield levelled off (Fig. 1). The delay observed in TSFO medium at the start of cultivation may be due to the presence of volatile growth inhibitory compounds in the medium, which over time might be neutralized by the yeast or partial or complete evaporation 
of these compounds. It is also possible that these compounds only inhibited the synthesis of lipase and emulsifying compounds, so the oil was not as readily available for the yeast as it was for the other mediums, in any case determination of the actual reason behind this observation is beyond the scope of this study. Interestingly such an inhibitory effect was not observed for the samples from ISFO medium, where oil was treated very similarly (Fig. 1). Only difference being that ISFO contained trace amounts of potato chips which might serve as carbon source in the first days of the cultivation and after that lipases and emulsifying compounds were synthesized in appropriate concentration for the yeast to switch the nutrient sources.

In the first three days, untreated sunflower oil medium (SFO) showed significantly faster protein accumulation than TSFO and ISFO media (Fig. 1), which indirectly indicates the effect of inhibitory compounds on Yarrowia lipolytica cultures in TSFO and ISFO.

For SFO, TSFO, ISFO and YNB mediums, the same ingredient base and $\mathrm{C} / \mathrm{N}$ ratios were used to compare the effect of carbon source on protein production. The protein yield did not differ significantly from ISFO media (Fig. 1), from which it can be concluded that Yarrowia lipolytica is equally effective in using both WCO and glucose as a carbon source, which indicates the advantages of WCO, as it is not only significantly cheaper, but also has 1.89 times higher energy capacity than glucose.

\section{Protein yields over time for $12.5 \mathrm{~g} / \mathrm{L}, \mathrm{C} / \mathrm{N} 15$ samples}

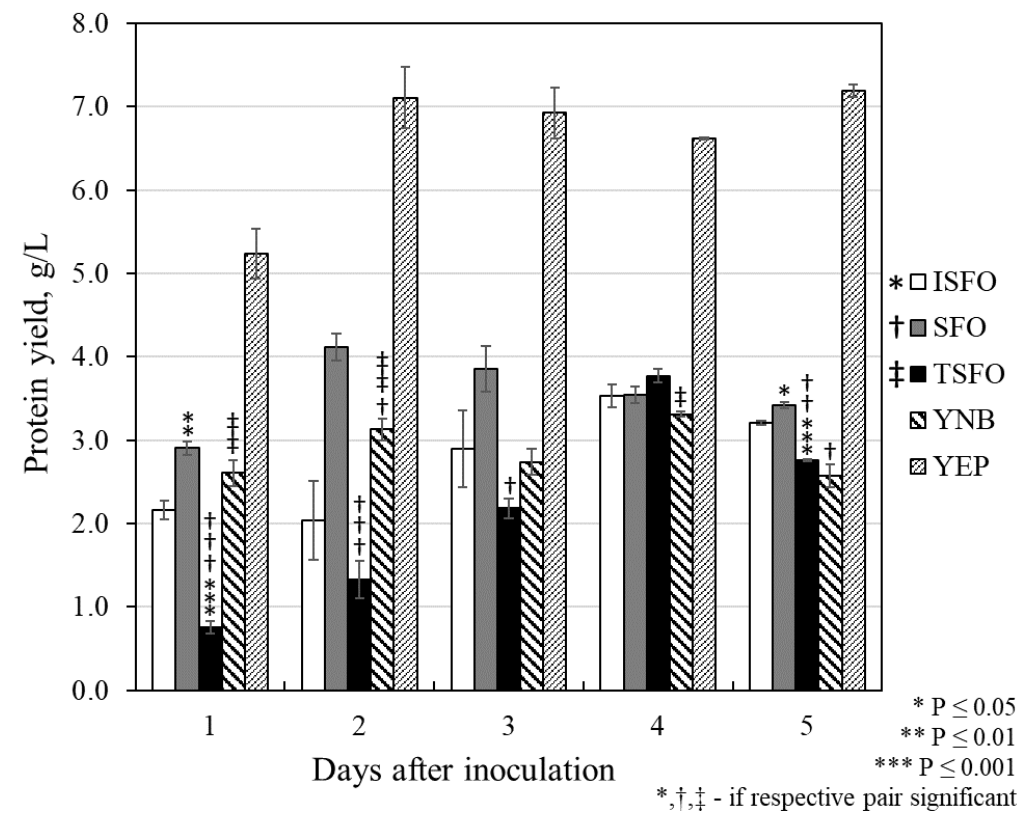

Fig. 1. Change in Yarrowia lipolytica protein yields over time when cultivated on control samples (YEP, YNB, SFO, TSFO) and test samples (ISFO). YEP - yeast extract peptone medium (optimal), containing 23.66 g/L glucose, which is equivalent to $12.5 \mathrm{~g} / \mathrm{L}$ of sunflower oil, unknown $\mathrm{C} / \mathrm{N}$ ratio due to peptone and yeast extract. YNB - yeast nitrogen base medium (minimal), containing $23.66 \mathrm{~g} / \mathrm{L}$ glucose, $\mathrm{C} / \mathrm{N}$ ratio 15 . SFO, TSFO, ISFO - same composition as YNB medium only with glucose replaced by $12.5 \mathrm{~g} / \mathrm{L}$ of untreated, treated or industrial (WCO) sunflower oil respectively, $\mathrm{C} / \mathrm{N}$ ratio 15 . Error bars - standard deviation. Significance test $-t$-Test $(*, \uparrow, \uparrow$ represent the respective pairing if statistically different, e.g. if column has $\dagger$ on top of it, it means that SFO result is statistically different to result in respective column), all pairings with YEP results were significant (not shown). Cultivation was done in $50 \mathrm{ml}$ flasks containing $15 \mathrm{ml}$ medium, $200 \mathrm{rpm}, 28^{\circ} \mathrm{C}$, triplets. 


\subsection{Optimal WCO Concentration}

Comparing the protein yields in the mediums varying with the WCO concentrations, the highest protein yield $(6.02 \mathrm{~g} / \mathrm{L})$ was reached on the fourth day at $27.5 \mathrm{~g} / \mathrm{L}$ WCO concentration (Fig. 2). For the $20 \mathrm{~g} / \mathrm{L}$ and $35 \mathrm{~g} / \mathrm{L}$ WCO samples, the results were similar at $5.48 \mathrm{~g} / \mathrm{L}$ and $5.26 \mathrm{~g} / \mathrm{L}$, respectively (Fig. 2). The direction of the curve for the $35 \mathrm{~g} / \mathrm{L}$ samples suggests that it is possible that the protein yield could increase with prolonged cultivation, so it was tested by measuring the change in biomass concentration over six days (Fig. 3). The results showed that at sixth day culture in this medium also undergoes a death phase (Fig. 3), therefore a higher increase in protein yield cannot be expected if cultivations are prolonged past 4 days. Interestingly, higher protein yields in the first days of cultivation are achieved in mediums with lower WCO concentrations (Fig. 2, $12.5 \mathrm{~g} / \mathrm{L}$ WCO on day 1, $20 \mathrm{~g} / \mathrm{L}$ WCO on day 2 and 3 ), which suggests that yeast initiates exponential growth only when the oil is sufficiently emulsified or the ratio of synthesized extracellular lipases to WCO concentration in the medium has reached a certain limit. This observation is also supported by visual changes in the consistency of the media over time (Fig. 4). Overall, $27.5 \mathrm{~g} / \mathrm{L}$ can be considered optimal WCO concentration for SCP production in batch fermentations, although no statistically significant differences were observed between the $20 \mathrm{~g} / \mathrm{L}, 27.5 \mathrm{~g} / \mathrm{L}, 35 \mathrm{~g} / \mathrm{L}$ samples on the fourth or the fifth day (Fig. 2), therefore there is reason to believe that oil concentrations can be varied in the range of 20-35 g/L without significantly compromising the SCP yields.

\section{Protein yields over time for ISFO samples with variable WCO concentrations, $\mathrm{C} / \mathrm{N} 15$}

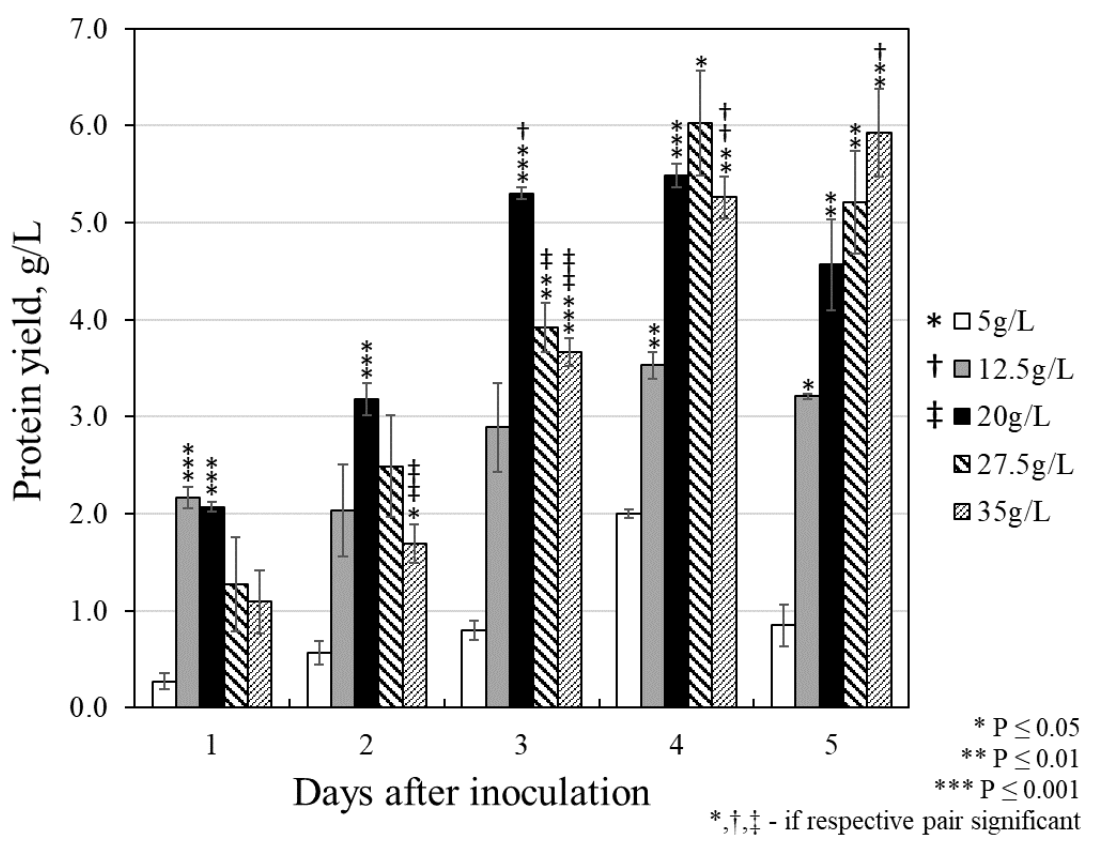

Fig. 2. Change in Yarrowia lipolytica protein yields over time when cultivated in mediums containing variable concentrations of industrial (WCO) sunflower oil. All mediums had C/N ratio of 15. Error bars - standard deviation. Significance test $-t$-Test $(*, \dagger, \uparrow$ represent the respective pairing if statistically different). All samples cultivated in $50 \mathrm{ml}$ flasks containing $15 \mathrm{ml}$ medium, $200 \mathrm{rpm}, 28^{\circ} \mathrm{C}$, triplets. 


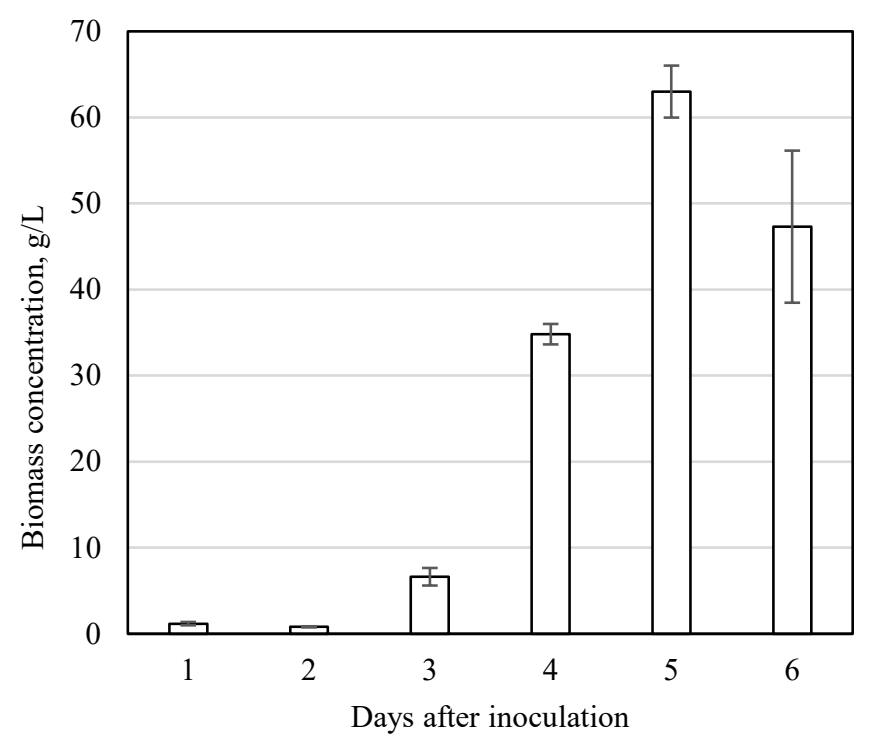

Fig. 3. Biomass concentration over time for ISFO medium containing $35 \mathrm{~g} / \mathrm{L}$ WCO, $\mathrm{C} / \mathrm{N}$ ratio 15 . Error bars standard deviation. All samples cultivated in $50 \mathrm{ml}$ flasks containing $15 \mathrm{ml}$ medium, $200 \mathrm{rpm}, 28^{\circ} \mathrm{C}$, triplets.

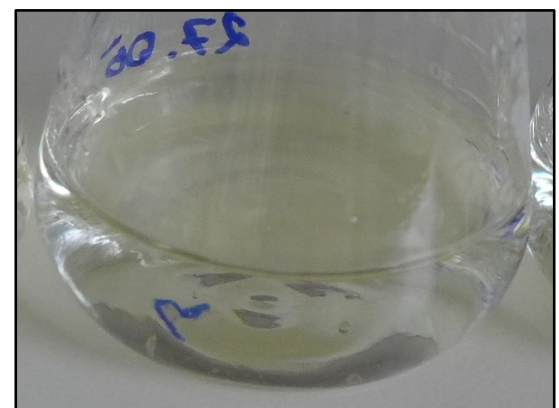

A1, Day 1

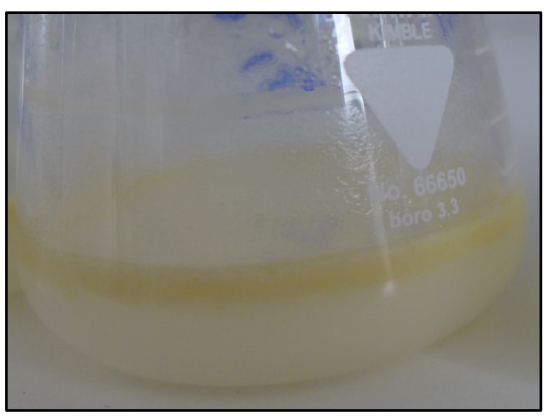

A3, Day 3

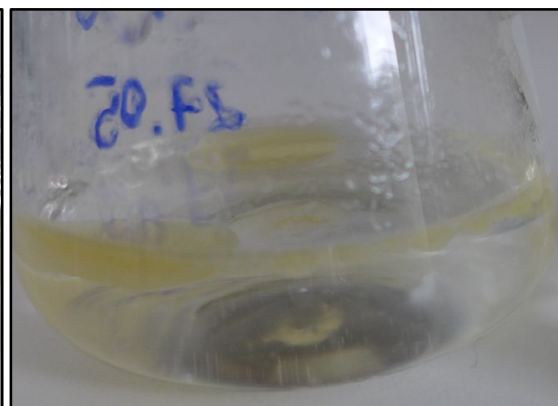

A2, Day 2

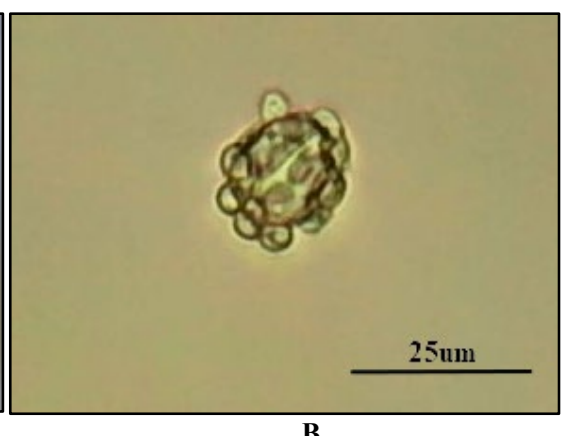

B

Fig. 4. A) WCO emulsification by Yarrowia lipolytica over time; B) Yarrowia lipolytica around an emulsified WCO droplet (400x magnification), second day after inoculation. 


\subsection{Optimal C/N Ratio}

It is rational to propose that the media with the lowest $\mathrm{C} / \mathrm{N}$ ratio are most likely to achieve the highest protein yields, as the media will have higher nitrogen concentration, which is a limiting element for protein synthesis. In this case, it was surprising that this was only partially confirmed, with the highest protein yield $(4.30 \mathrm{~g} / \mathrm{L})$ reached on third day of medium with $\mathrm{C} / \mathrm{N} 5$, while medium with $\mathrm{C} / \mathrm{N} 10$ reached the second highest protein yield $(4.14 \mathrm{~g} / \mathrm{L})$ on the fourth day (Fig. 5). Also on the third day, no statistically significant difference was observed between mediums with $\mathrm{C} / \mathrm{N}$ ratios 5, 10 and 15 (Fig. 5). It is possible that higher protein yields could be reached if $\mathrm{C} / \mathrm{N}$ ratios would be lower than 5 , but since no significant difference was observed between $\mathrm{C} / \mathrm{N} 5$ and 10 ratio samples on any of the days, the most likely optimal $\mathrm{C} / \mathrm{N}$ ratio for SCP production using this $\mathrm{WCO}$ is in the range of 5 to 10 .

\section{Protein yields over time for ISFO samples with variable $\mathrm{C} / \mathrm{N}$ ratios, $12.5 \mathrm{~g} / \mathrm{L}$ WCO}

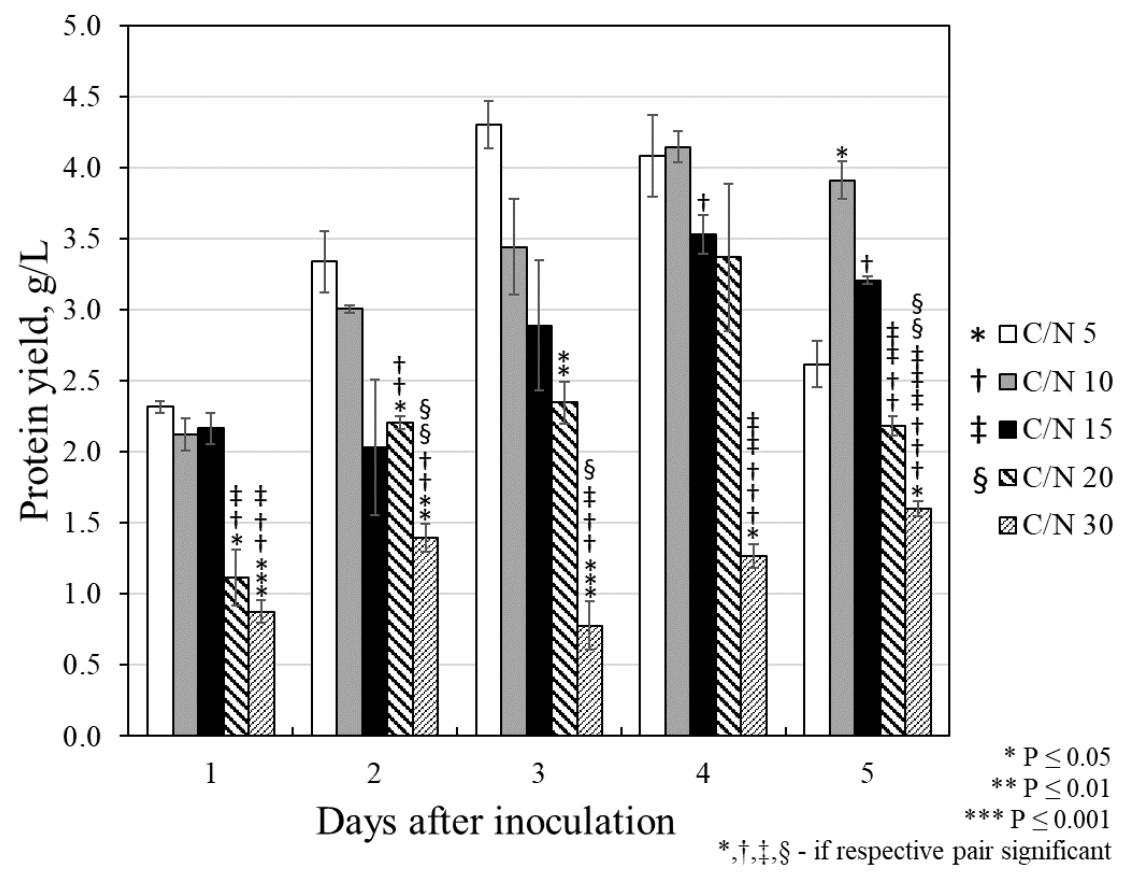

Fig. 5. Change in Yarrowia lipolytica protein yields over time when cultivated in mediums containing variable $\mathrm{C} / \mathrm{N}$ ratios. All mediums had the same concentration of industrial (WCO) sunflower oil (12.5 g/L). Error bars - standard deviation. Significance test $-t$-Test $(*, \dagger, \$, \S$ represent the respective pairing if statistically different). All samples cultivated in $50 \mathrm{ml}$ flasks containing $15 \mathrm{ml} \mathrm{medium,} 200 \mathrm{rpm}, 28{ }^{\circ} \mathrm{C}$, triplets.

\subsection{Changes in MDA Concentrations}

Initial MDA concentrations for TSFO and ISFO oil samples were high, 32.31 and $30.87 \mathrm{mg}$ MDA $/ \mathrm{kg}$, respectively (Table 1). Any oils with MDA concentration above $3.7 \mathrm{mg} / \mathrm{kg}$ of product are considered rancid. As the highest protein yield was reached on the fourth day, MDA measurements were also performed on samples harvested on the fourth day using the optimal medium composition (27.5 g/L oil, C/N10). MDA analysis was also performed on 
the respective samples on the first day of cultivation to compare changes in MDA concentration over time as the biomass increased exponentially. Yeast biomass cultivated on untreated sunflower oil (SFO) showed safe levels of MDA on the fourth day of cultivation, $0.14 \mathrm{mg} \mathrm{MDA} / \mathrm{kg}$ of biomass (Table 2). For meat products, safe concentrations of MDA are considered to be $<2.0 \mathrm{mg} \mathrm{MDA} / \mathrm{kg}$ of product. Yeast biomass cultivated on both TSFO and ISFO oils exceeded this limit at 2.42 and $2.32 \mathrm{mg} \mathrm{MDA} / \mathrm{kg}$ biomass, respectively (Table 2). Consequently, SCP obtained by cultivating yeast on WCO cannot be considered safe for use in animal feeds. Of course, SCP is usually fed in a mixture with other feed ingredients, thus reducing the total concentration of MDA in the feed, but this would not be recommended given the toxicity of MDA. The sharp decrease in MDA concentration in yeast biomass samples can be explained by the fact that part of MDA accumulated in yeast cells only partially and part of MDA remained in the medium, or MDA reacted with DNA and protein molecules in yeast cells. Adduct formation and toxic effects of MDA on yeast cells may also explain the marked delay in culture development observed in TSFO medium (Fig. 1), as significantly higher concentrations of MDA were detected in TSFO samples on the first day than in other samples (Table 2). As the biomass cultivated on WCO showed a significant reduction in MDA concentration, from 9.75 to $2.32 \mathrm{mg} \mathrm{MDA} / \mathrm{kg}$, it is reasonable to suggest that adapting the use of WCO substrate in larger volumes using a bioreactor and thus achieving significantly higher yeast biomass concentrations could reduce MDA to safe levels. To the best of the authors' knowledge this is the first study to report on MDA decrease via microbial fermentations. Further research is needed not only to optimize the production of various fermentation products when using $\mathrm{WCO}$, but also to understand the biochemical mechanism that ensures the reduction of MDA concentration in the microbial biomass.

TABLE 1. MDA CONCENTRATIONS IN OIL SAMPLES

\begin{tabular}{cc}
\hline Oil sample & mg MDA/kg of sample \\
\hline SFO & 1.50 \\
TSFO & 32.31 \\
ISFO & 30.87
\end{tabular}

Note: SFO - untreated sunflower oil, TSFO - treated sunflower oil, ISFO - industrial (WCO) sunflower oil

TABLE 2. CHANGE In MDA CONCENTRATIONS OVER TIME IN YARROWIA LIPOLYTICA BiOMASS

\begin{tabular}{|c|c|c|c|c|}
\hline \multirow{2}{*}{ Medium } & \multicolumn{2}{|c|}{ Day 1} & \multicolumn{2}{|c|}{ Day 4} \\
\hline & g biomass/L & mg MDA/kg & g biomass/L & mg MDA/kg \\
\hline SFO & 8.89 & 6.32 & 50.75 & 0.14 \\
\hline TSFO & 2.56 & 18.02 & 52.22 & 2.42 \\
\hline ISFO & 6.81 & 9.75 & 57.88 & 2.32 \\
\hline
\end{tabular}

Note: Yeast cultivated in optimal mediums containing 27.5 of appropriate oil and $\mathrm{C} / \mathrm{N}$ ratio 10

In this study, the highest reported Yarrowia lipolytica biomass concentration $(57.37 \mathrm{~g} / \mathrm{L})$ was reached when cultivated on medium containing $\mathrm{WCO}$ as the main carbon source. Papanikolaou et al. [32] and Yan et al. [33] achieved $30.5 \mathrm{~g} / \mathrm{L}$ and $17.9 \mathrm{~g} / \mathrm{L}$, respectively. The protein concentrations obtained in this study were relatively low for optimal ISFO medium (12.6\%), while Yan et al. [33] reported protein concentrations ranged from 45 to $54 \%$. Therefore, it can be concluded that by selecting and replacing wild type with better adapted mutants or genetically engineered strains, it is possible to significantly increase the Yarrowia lipolytica protein yields. In addition, as no significant differences were observed in the ability of Yarrowia lipolytica to efficiently utilize both glucose and WCO, fermentation scale-up to higher volume bioreactors with controlled $\mathrm{pH}$ and oxygen concentrations would 
allow much higher biomass and protein concentrations to be achieved. By using WCO as a substrate in this way, it would be possible to achieve similar biomass concentrations as reported by other research groups. Yan et al. [33] reported on achieving a record high biomass concentration of $151.2 \mathrm{~g} / \mathrm{L}$ by engineered Yarrowia lipolytica in a $10 \mathrm{~L}$ bioreactor using molasses as a main carbon source.

\section{Conclusions}

Waste cooking oil is a cheap and energy-dense by-product that can be used in microbiological fermentations to produce a range of value-added products, including single cell protein. Yarrowia lipolytica is able to use WCO effectively without the need to emulsify WCO prior fermentation with either emulsifiers or ultrasonification. Thus, the use of Yarrowia lipolytica can significantly reduce the cost of using WCO. Single cell proteins are microbial biomass that can be used as a protein-rich raw material for animal and human consumption. During the heating of WCO, a number of toxic compounds are formed, so when WCO is used as a substrate in the production of SCP, this study investigated the obtainable SCP yields and the accumulation of toxic compounds in the resulting microbial biomass.

In terms of protein yield, no significant differences were observed between carbon sources (glucose and industrial sunflower oil) from which it can be concluded that WCO from potato chip processing is a very promising and cheap carbon source for cultivating Yarrowia lipolytica with almost twice the energy capacity as glucose (1.89 times).

The medium containing $27.5 \mathrm{~g} / \mathrm{L}$ WCO and $\mathrm{C} / \mathrm{N}$ ratio of 5-10 for batch fermentations was determined to be the optimal composition for SCP production. In this study, the highest reported Yarrowia lipolytica biomass concentration $(57.37 \mathrm{~g} / \mathrm{L})$ was achieved when WCO was used as the main carbon source. Protein concentrations were relatively low (12.6\%), which also affected the final protein yield $(7.23 \mathrm{~g} / \mathrm{L})$. The resulting biomass accumulated low concentrations of toxic malondialdehyde (MDA) $(2.32 \mathrm{mg}$ MDA $/ \mathrm{kg}$ ) when compared to concentrations initially detected in the WCO itself $(30.87 \mathrm{mg} \mathrm{MDA} / \mathrm{kg})$. If use of WCO in fermentations are further developed by reaching MDA concentrations below $2.0 \mathrm{mg} / \mathrm{kg}$, the resulting SCP would be safe for use in animal feeds, which would provide significant economic benefits, while at the same time significantly reducing the negative environmental impacts by treating WCO.

\section{ACKNOWLEDGEMENT}

The work has been supported by ERDF project KC-PI-2017/60 "Supercritical Omega-3 oil from production by-products" managed by the Investment and Development Agency of Latvia (LIAA).

\section{REFERENCES}

[1] Wei Z., et al. Determination and removal of malondialdehyde and other 2-thiobarbituric acid reactive substances in waste cooking oil. Journal of Food Engineering 2011:107(3-4):379-384. https://doi.org/10.1016/i.jfoodeng.2011.06.032

[2] Kumar S., Negi S. Transformation of waste cooking oil into C-18 fatty acids using a novel lipase produced by Penicillium chrysogenum through solid state fermentation. Biotech 2015:5:847-851. https://doi.org/10.1007/s13205$\underline{014-0268-\mathrm{Z}}$

[3] de Araujo M. C. D., et al. Biodiesel production from used cooking oil: a review. Renewable and Sustainable Energy Reviews 2013:27:445-452. https://doi.org/10.1016/j.rser.2013.06.014 
[4] Nanou K., Roukas T. Waste cooking oil: A new substrate for carotene production by Blakeslea trispora in submerged fermentation. Bioresource Technology 2016:203:198-203. https://doi.org/10.1016/j.biortech.2015.12.053

[5] Phan A. N., Phan T. M. Biodiesel production from waste cooking oils. Fuel 2008:87(17-18):3490-3496. https://doi.org/10.1016/j.fuel.2008.07.008

[6] Talebian-Kiakalaieh A., Amin N. A. S., Mazaheri H. A review on novel processes of biodiesel production from waste cooking oil. Applied Energy 2013:104:683-710. https://doi.org/10.1016/j.apenergy.2012.11.061

[7] Sheinbaum-Pardo C., Calderon-Irazoque A., Ramirez-Suarez M. Potential of biodiesel from waste cooking oil in Mexico. Biomass Bioenergy 2013:56:230-238. https://doi.org/10.1016/j.biombioe.2013.05.008

[8] Cvengros J., Cvengrosova Z. Used frying oils and fats and their utilization in the production of methyl esters of higher fatty acids. Biomass Bioenergy 2004:27(2):173-181. https://doi.org/10.1016/j.biombioe.2003.11.006

[9] Kulkarni M. G., Dalai A. K. Waste cooking oil - An economical source for biodiesel: a review. Industrial and Engineering Chemistry Research 2006:45:2901-2913. https://doi.org/10.1021/ie0510526

[10] Choe E., Min D. B. Chemistry of deep-fat frying oils. Journal of Food Science 2007:72(5):77-86. https://doi.org/10.1111/j.1750-3841.2007.00352.x

[11] Steinberg D., Witztum J. L. Lipoproteins and atherogenesis: current concepts. Journal of American Medicine Association 1990:246:3047-3052.

[12] Grootveld M., et al. Health effects of oxidized heated oils. Foodservice Research International 2001:41-55. https://doi.org/10.1111/j.1745-4506.2001.tb00028.x

[13] Maddikeri G. L., Gogate P. R., Pandit A. B. Improved synthesis of sophorolipids from waste cooking oil using fed batch approach in the presence of ultrasound. Chemical Engineering Journal 2015:263:479-487. https://doi.org/10.1016/j.cej.2014.11.010

[14] Bailey A. E. Bailey's Industrial Oil and Fat Products. New York: John Wiley \& Sons, 2005.

[15] Torun M., et al. Serum beta-carotene, vitamin-E, vitamin-C and malondialdehyde levels in several types of cancer. Journal of Clinical Pharmacy and Therapeutics 1995:20(5):259-263. https://doi.org/10.1111/j.13652710.1995.tb00660.x

[16] Papastergiadis A., et al. Malondialdehyde Measurement in Oxidized Foods: Evaluation of the Spectrophotometric Thiobarbituric Acid Reactive Substances (TBARS) Test in Various Foods. Journal of agricultural and food chemistry 2012:60:9589-9594. https://doi.org/10.1021/jf302451c

[17] Frankel N.E. Lipid Oxidation. UK: The Oily Press, 2005.

[18] Esterbauer H., Schaur R. J., Zollner H. Chemistry and biochemistry of 4-hydroxynonenal, malonaldehyde and related aldehydes. Free Radical Biology and Medicine 1991:11(1):81-128. https://doi.org/10.1016/0891-5849(91)90192-6

[19] Uchida K. Histidine and lysine as targets of oxidative modification. Amino Acids 2003:25(3-4):249-257. https://doi.org/10.1007/s00726-003-0015-y

[20] Giera M., Lingeman H., Niessen W. M. Recent advancements in the LC- and GC-based analysis of malondialdehyde (MDA): A brief overview. Chromatographia 2012:75(9-10):433-440. https://doi.org/10.1007/s10337-012-2237-1

[21] Botsoglou N. A., et al. Rapid, sensitive, and specific thiobarbituric acid method for measuring lipidperoxidation in animal tissue, food, and feedstuff samples. Journal of Agricultural and Food Chemistry 1994:42(9):1931-1937. https://doi.org/10.1021/jf00045a019

[22] Guillen-Sans R., Guzman-Chozas M. The thiobarbituric acid (TBA) reaction in foods: A review. Critical Reviews for Food Science and Nutritions 1998:38(4):315-330. https://doi.org/10.1080/10408699891274228

[23] Du Z., Bramlage W. J. Modified thiobarbituric acid assay for measuring lipid oxidation in sugar-rich plant tissue extracts. Journal of Agricultural and Food Chemistry 1992:40(9):1566-1570. https://doi.org/10.1021/jf00021a018

[24] Devasagayam T. P. A., Boloor K. K., Ramasarma T. Methods for estimating lipid peroxidation: An analysis of merits and demerits. Indian Journal of Biochemistry \& Biophysics 2003:40:300-308.

[25] Jacobson M., Koehler H. H. Development of rancidity during short-time storage of cooked poultry meat. Journal of Agricultural and Food Chemistry 1970:18(6):1069-1072. https://doi.org/10.1021/jf60172a010

[26] Kerth C. R., Legako J. Flavor Development and Relating Volatile compounds to Sensory Evaluation. American Meat Science Association 2015:27-31.

[27] Khidhir Z., et al. Lipid oxidation as a quality indicator in meats for Five local Fresh Fish. Presented at the 1 st Scientific Conference for Food Sciences, Tikrit, Iraq, 2013.

[28] Liu X. Y., Lv J. S., Xu J. X. Effects of osmotic pressure and $\mathrm{pH}$ on citric acid and erythritol production from waste cooking oil by Yarrowia lipolytica. Engineering in Life and Science 2018:18(6):344-52. https://doi.org/10.1002/elsc.201700114

[29] Patel A., Matsakas L. A comparative study on de novo and ex novo lipid fermentation by oleaginous yeast using glucose and sonicated waste cooking oil. Ultrasonics - Sonochemistry 2019:52:364-374. https://doi.org/10.1016/j.ultsonch.2018.12.010

[30] Katre G., et al. Evaluation of single cell oil (SCO) from a tropical marine yeast Yarrowia lipolytica 3589 as a potential feedstock for biodiesel. AMB Express 2012:2:36. https://doi.org/10.1186/2191-0855-2-36 
[31] Katre G., et al. Optimization of the in situ transesterification step for biodiesel production using biomass of Yarrowia lipolytica NCIM 3589 grown on waste cooking oil. Energy 2018:142:944-952. https://doi.org/10.1016/j.energy.2017.10.082

[32] Papanikolaou S., et al. Industrial derivative of tallow: a promising renewable substrate for microbial lipid, single-cell protein and lipase production by Yarrowia lipolytica. Electronic Journal of Biotechnology 2007:10(3):426-435 https://doi.org/10.2225/vol10-issue3-fulltext-8

[33] Yan J., et al. Engineering Yarrowia lipolytica to Simultaneously Produce Lipase and Single Cell Protein from Agroindustrial Wastes for Feed. Scientific reports 2018:8:758. https://doi.org/10.1038/s41598-018-19238-9

[34] Liu X., et al. A cost-effective process for the coproduction of erythritol and lipase with Yarrowia lipolytica M53 from waste cooking oil. Food and Bioproducts Processing 2017:103:86-94. https://doi.org/10.1016/j.fbp.2017.03.002

[35] Dominguez A., et al. Biodegradation and utilization of waste cooking oil by Yarrowia lipolytica CECT 1240. European Journal of Lipid Science and Technology 2010:112:1200-1208. https://doi.org/10.1002/ejlt.201000049

[36] Suci M., Arbianti R., Hermansyah H. Lipase production from Bacillus subtilis with submerged fermentation using waste cooking oil. IOP Conf. Series: Earth and Environmental Science 2018:105:012126. https://doi.org/10.1088/1755-1315/105/1/012126

[37] Liu X., et al. Citric Acid Production in Yarrowia lipolytica SWJ-1b Yeast When Grown on Waste Cooking Oil. Applied Biochemistry and Biotechnology 2014:175(5). https://doi.org/10.1007/s12010-014-1430-0

[38] Anupama, Ravindra P. Value-added food: single cell protein. Biotechnology Advances 2000:18:459-479. https://doi.org/10.1016/S0734-9750(00)00045-8

[39] Ritala A., et al. Single Cell Protein-State-of-the-Art, Industrial Landscape and Patents 2001-2016. Frontiers in Microbiology 2017:8:2009. https://doi.org/10.3389/fmicb.2017.02009

[40] Ugalde U. O., Castrillo J. I. Applied mycology and biotechnology. Agriculture and Food Production 2002:2:123-149.

[41] Mekonnen M. M., Howkstra A. Y. Water footprint benchmarks for crop production: A first global assessment. Ecological Indicators 2014:46:214-223. https://doi.org/10.1016/j.ecolind.2014.06.013

[42] Tilman D. Global environmental impacts of agricultural expansion: the need for sustainable and efficient practices. Proceedings of the National Academy of Sciences of the United States of America 1999:96(11):5995-6000. https://doi.org/10.1073/pnas.96.11.5995

[43] Vermeulen S. J., Campbell B. M., Ingram J. S. I. Climate Change and Food Systems. Annual Review of Environment and Resources 2012:37:195-222.

[44] Sitepu I. R., et al. Oleaginous yeasts for biodiesel: current and future trends in biology and production. Biotechnology Advances 2014:32(7):1336-1360. https://doi.org/10.1016/j.biotechadv.2014.08.003

[45] Patel A., et al. Synergistic effect of fermentable and non-fermentable carbon sources enhances TAG accumulation in oleaginous yeast Rhodosporidium kratochvilovae HIMPA1. Bioresource Technology 2015:188:136-144. https://doi.org/10.1016/j.biortech.2015.02.062

[46] Papanikolaou S., Aggelis G. Yarrowia lipolytica: a model microorganism used for the production of tailor-made lipids. European Journal of Lipid Science and Technology 2010:112:639-654. https://doi.org/10.1002/ejlt.200900197

[47] Fickers P., et al. Hydrophobic substrate utilisation by the yeast Yarrowia lipolytica, and its potential applications. FEMS Yeast Research 2005:5:527-543. https://doi.org/10.1016/j.femsyr.2004.09.004

[48] Thevenieau F., et al. Uptake and assimilation of hydrophobic substrates by the oleaginous yeast Yarrowia lipolytica. Handbook of Hydrocarbon and Lipid Microbiology 2010:1:1513-1661. https://doi.org/10.1007/978-3-540-775874104

[49] Garti N., et al. Improved oil solubilization in oil/water food grade microemulsions in the presence of polyols and ethanol. Journal of Agriculture and Food Chemistry 2001:49:2552-2562. https://doi.org/10.1021/jf001390b

[50] Sureshkumar K., Velraj R., Ganesan R. Performance and exhaust emission characteristics of a CI engine fuelled with Pongamia pinnata methyl ester (PPME) and its blends with diesel. Renewable Energy 2008:33(10):2294-2302. https://doi.org/10.1016/j.renene.2008.01.011

[51] Sestric R., et al. Growth and neutral lipid synthesis by Yarrowia lipolytica on various carbon substrates under nutrientsufficient and nutrient-limited conditions. Bioresource Technology 2014:164:41-46. https://doi.org/10.1016/j.biortech.2014.04.016

[52] Spalvins K., Ivanovs K., Blumberga D. Single cell protein production from waste biomass: review of various agricultural by-products. Agronomy Research 2018:16(S2):1493-1508. https://doi.org/10.15159/AR.18.129

[53] Spalvins K., Zihare L., Blumberga D. Single cell protein production from waste biomass: comparison of various industrial by-products. Energy Procedia 2018:147:409-418. https://doi.org/10.1016/j.egypro.2018.07.111

[54] Spalvins K., Blumberga D. Single cell oil production from waste biomass: review of applicable agricultural byproducts. Agronomy Research 2019:17(3):833-849. https://doi.org/10.15159/AR.19.039

[55] Spalvins K., Vamza I., Blumberga D. Single cell oil production from waste biomass: review of applicable industrial by-products. Environmental and Climate Technologies 2019:23(2):325-337. https://doi.org/10.2478/rtuect-2019-0071 